\title{
A Review of Sexual Harassment of Women at Workplace in the International Documents
}

\author{
Leila Ateffakhr \\ Research Scholar in Law, Kerala University, Thiruvananthapuram, India
}

\begin{abstract}
Sexual harassment is a violation of one's freedom and personal integrity. Sexual harassment includes such unwelcome sexually determined behavior as physical behavior and advances, sexually colored remarks, showing pornography and sexual demands, whether by words or actions. Sexual harassment can ruin the victim's life. Historically, sexual harassment is seen as perpetrated by men in possession of power (physical, political and economic) against women. So the UN has taken several initiatives to protect of women at the workplace such as the International Labor Organization 1919 (ILO).
\end{abstract}

Keywords:women, workplace, international documents, protection,sexual harassment.

\section{Introduction}

One of the basic requirements of a man or a woman is economic independence. Nowadays, women are trying to reach economic independence for combating inequality with men. But when the women go to the workplace for reaching their income many of them are faced with sexual harassment at the workplace, so the security and dignity of women at workplace is in danger. This offence is the obvious instance of human rights violation of gender equality and injustice.Generally harassment at workplace can come from her employer, a representative of her employer, a colleague etc. Though sexual harassment at workplace has been legally prohibited in some countries for more than two decades, until recently only some jurisdictions has enacted legislation on this issue.

\section{Defination of Sexual Harassment}

The sexual harassment definition comes from the United States Equal Employment Opportunity Commission 1965(EEOC), Under this Commission sexual harassment is "unwelcome sexual advances, requests for sexual favors and other verbal or physical conduct of a sexual nature constitutes sexual harassment when submission or rejection of this conduct explicitly or implicitly affects an individual's employment, unreasonably interferes with an individual's work environment".

Many countries across the world are embracing sexual harassment prevention legislations at the workplace similar to those established in the United Nations, yet the interpretations and enforcement of those legislations are unique to each state. This can be attributed to numerous cultural factors including: individualism, relativism and collectivism, legal and economic status of women and gender relation.[1]

\section{Type of Sexual Harassment}

Generally, there are two types of sexual harassment, Quid pro quo (meaning "this for that") and Hostile environment. Quid pro quo: Sexual harassment happens when it is stated or implied that an employment or academic decision about an employee or student depends upon whether the employee or student submits to conduct of a sexual nature. Sexual harassment also happens when it is stated or implied that an individual must submit to conduct of a sexual nature in order to participate in a University activity or program. So, for instance, if an employee is made to believe that a promotion is likely if the employee goes on a date with the employee's manager, the employee is possibly being subjected to sexual harassment.[2]

Hostile environment: sexual harassment happens when unwelcome behavior of a sexual nature creates a threatening, intimidating or abusive working or learning environment or is so intense, pervasive or persistent that it affects a person's capability to contribute in or benefit from a University program or activity. While a person engaging in harassing behavior usually has some form of authority or power over the person being harassed, that is not always the case. The harasser may be a peer of the person being harassed. Sometimes the harasser is harassing a person who has control over them. For instance, a supervisee can sexually harass a supervisor or a student can sexually harass a faculty member.[3]

\section{Sexual Harassment of Women at Work Place in International Document}

Sexual harassment is coercion or intimidation of a sexual nature, or the unwelcome or inappropriate promise of rewards in exchange for sexual favors.[2] According to Article 2 of United Nations Declaration on Violence against Women (1993), Violence against women shall be understood to encompass, but is not limited to physical, sexual and psychological violence including sexual harassment and intimidation at work.[3]

The International Labor Organization (ILO) 1919, it has passed a number of non-binding instruments which contain provisions on sexual harassment at work. The International Labor Conference Resolution in 1985 on equal treatment and equal opportunity for men andwomen in employment stated that "sexual harassment at the workplace is detrimental to employees' working conditions and to their employment and promotion prospects.'[4] 


\section{International Journal of Science and Research (IJSR) \\ ISSN (Online): 2319-7064 \\ Index Copernicus Value (2013): 6.14 | Impact Factor (2015): 6.391}

At the United Nations, the subject of sexual harassment at workplace has been addressed as both a manifestation of sex discrimination and a form of violence against women.The 1979 Convention on the Elimination of All Forms of Discrimination Against Women (CEDAW) was adopted at the time when awareness of sexual harassment was only start to emerge and did not so contain a specific prohibition. However, the Committee on the Elimination of Discrimination Against Women, set up under the Convention, has since obviously addressed the problem. It is General Recommendation of recognized sexual harassment as a form of violence against women in 1989.[5] years later, in generalrecommendationthe Committee characterized gender-based violence as a form of sex discrimination and therefore a breach of CEDAW.[6]

The Recommendation notes that "equality in employment can be seriously impaired when women are subjected to gender-specific violence, such as sexual harassment in the workplace". The Committee recommended that parties to the treaty should take all legal and other actions necessary to provide effective protection for women against gender-based violence, containing sexual harassment in the workplace.

The work of the Committee was drawn on in developing the 1993 General Assembly Declaration on the Elimination of Violence Against Women, which confirms that this form of violence constitutes a violation of women's rights and fundamental freedoms.[7] It defines violence against women to encompass "sexual harassment and intimidation at work", and calls on States to convict it and follow a strategy to eliminate it. Sexual harassment has also been addressed in the human rights context. The World Conference on Human Rights, held in Vienna in 1993, identified it as a human rights violation, [8] while the Commission on Human Rights has treated it primarily as a form of violence against women. The Commission appointed a Special Rapporteur in 1995, whose work has included investigation on sexual harassment at work and the actions which can be taken to prevent it. [9]

The United Nations Fourth World Conference on Women, held in Beijing in 1995, adopted a Platform for Action, which plans strategic objectives and actions to be taken by a range of actors, contains provisions on sexual harassment in the workplace. [10] It arranges the problem as both a form of violence against women, and an obstacle to their equality, stating, the experience of sexual harassment is an affront to a worker's dignity and prevents women from making a contribution equal with their abilities. The Platform calls on governments, trade unions, employers, community and youth organizations, and NGOs to eliminate sexual harassment. [11]

More specifically, governments are urged to enact and apply laws and administrative measures on sexual and other forms of harassment in the workplace. Parties.[12] at the enterprise level are called upon to extend workplace policies. At the June 2000 specific Session of the General Assembly on Women 2000: Gender equality, development and peace for the twenty-first century, governments assessed the achievements and the barriers which have been faced since the Beijing Conference. The Session created a set of more actions and initiatives to implement the Beijing Declaration and Platform for Action, which again address workplace sexual harassment.[13]

The ILO has addressed sexual harassment in a range of instruments and during debates at tripartite meetings. It has also conducted investigation and training on the issue, and provided information and technical help to its constituents. Lately, it has been emphasized that the elimination of sexual harassment and violence at the workplace is an important element in promoting decent work for women.[14] Recently, in November 2003, the ILO's Governing Body adopted the Code of practice on workplace violence in services sectors and measures to combat this phenomenon, a non-binding instrument which offers guidance in addressing workplace violence in these sectors and which makes specific reference to sexual harassment.[15]

\section{Conclusion}

Thus, duties and responsibilities of managers and supervisors should be clear for eliminating and preventing harassment at workplace. Managers and supervisors should be specially trained to recognize and handle harassment. Trade union involvement it is significant that workers are involved in the development of the policy and the role of trade union representatives is vital to this. Ultimately any complaint should be taken seriously and examined objectively. Any response must take into account any problems that might arise and ensure that sufficient support for the person making the complaint is available.

\section{Reference}

[1] Dr. S.K. Mukherjee, Law Relating To Sexual Harassment And Sexual Offences 24, (First Ed. 2010)

[2] What is sexual harassment, (May 2, 216), https://umich.edu/article/63 Supra note 2

[3] Paludi, Michele Antonette, Sexual Harassment 2-5, (First Ed. 2002)

[4] The Un Declaration On Violence Against Women, Art 2, December 20, (1993)

[5] Geneva,Official Bulletin , Lxviii, Series A, No. 2 8595, (1985)

[6] General Recommendation, Violence Against Women, No. 12, Eighth Session, (1989)

[7] The CEDAW, General Recommendations, Violence ,Against Women, No. 19, 11th Session, (1992)

[8] Declaration On The Elimination Of Violence Against Women, General Assembly, 85th Plenary Meeting, December 20, (1993)

[9] World Conference On Human Rights, Vienna Declaration And Programme Of Action, Un Documents, A/Conf.157/23, June 25, (1993)

[10] UN Commission On Human Rights, Question Of Integrating The Human Rights Of Women Into The Human Rights Mechanisms Of The United Nations, March 8, (1995)

[11] Beijing Declaration ,The Fourth World Conference On Women, The Predecessor To The Beijing Platform For Action, The Nairobi Forward-Looking Strategies For The Advancement Of Women , September 4-15, (1995) 


\section{International Journal of Science and Research (IJSR) \\ ISSN (Online): 2319-7064}

Index Copernicus Value (2013): 6.14 | Impact Factor (2015): 6.391

[12] Deirdre Mccann, Sexual Harassment At Work: National And International Responses , Isbn 92-2115798-9 Conditions Of Work And Employment Series No. 2, 20 (2005)

[13] UN General Assembly, Further Actions And Initiatives To Implement The Beijing Declaration And Platform For Action, Paragraph 178, November 16, (2000)

[14] Supra Note 12, At Paragraph 21,56, UNGeneral Assembly, Further Actions And Initiatives To Implement The Beijing Declaration And Platform For Action, Paragraph 21 November 16, (2000)

[15] Governing Body Geneva, Committee On Employment And Social Policy Esp, Ilo, 279th Session, , November 21, (2000)

[16] Geneva: International Labor Office, Workplace Violence In Services Sectors And Measures To Combat This Phenomenon, Ilo Code Of Practice, (2004).

[17] Unison's Communications Unit, Published And Printed By Unison, 1 Mable Don Place, London Wc1h 9aj. (August 6, 2015), Www.Unison.Org.U, $\mathrm{Cu} /$ October2008/17763/Stock Number 1359/Unp10336

\section{Author Profile}

Lila Ateffakhr, took her Post Graduation in Criminology of Azad University in 2008. she has five years experience in the Bar Association in Tehran as an Advocate. she is currently pursuing her Ph.D. in Violence against women and ciminal law: problems and perspectives, University of Kerala, India. 